\title{
Filmless versus film-based systems in radiographic examination costs: an activity-based costing method
}

\author{
Hiroshi Muto', Yuji Tani², Shigemasa Suzuki , Yuki Yokooka', Tamotsu Abe1, Yuji Sase', Takayoshi Terashita ${ }^{1}$ and \\ Katsuhiko Ogasawara ${ }^{*}$
}

\begin{abstract}
Background: Since the shift from a radiographic film-based system to that of a filmless system, the change in radiographic examination costs and costs structure have been undetermined. The activity-based costing (ABC) method measures the cost and performance of activities, resources, and cost objects. The purpose of this study is to identify the cost structure of a radiographic examination comparing a filmless system to that of a film-based system using the $A B C$ method.
\end{abstract}

Methods: We calculated the costs of radiographic examinations for both a filmless and a film-based system, and assessed the costs or cost components by simulating radiographic examinations in a health clinic. The cost objects of the radiographic examinations included lumbar (six views), knee (three views), wrist (two views), and other. Indirect costs were allocated to cost objects using the ABC method.

Results: The costs of a radiographic examination using a filmless system are as follows: lumbar 2,085 yen; knee 1,599 yen; wrist 1,165 yen; and other 1,641 yen. The costs for a film-based system are: lumbar 3,407 yen; knee 2,257 yen; wrist 1,602 yen; and other 2,521 yen. The primary activities were "calling patient," "explanation of scan," "take photographs," and "aftercare" for both filmless and film-based systems. The cost of these activities cost represented $36.0 \%$ of the total cost for a filmless system and $23.6 \%$ of a film-based system.

Conclusions: The costs of radiographic examinations using a filmless system and a film-based system were calculated using the $A B C$ method. Our results provide clear evidence that the filmless system is more effective than the film-based system in providing greater value services directly to patients.

\section{Background}

In Japanese healthcare institutions, the costs and cost structures of radiographic examinations have changed following installation of picture achieving and communication system (PACS) to improve the efficiency and quality of radiology departments operations. However, precisely estimating the cost of the examination is difficult from an efficiency viewpoint because it comprises several overheads common to various examinations (e.g., equipment expenses labor costs). While direct costs can be readily and conveniently traced to a particular

\footnotetext{
* Correspondence: oga@hs.hokudai.ac.jp

'Graduate School of Health Sciences, Hokkaido University, N12W5, Kita-ku, Sapporo, 060-0812, Japan

Full list of author information is available at the end of the article
}

examination, this is not true for indirect costs. In traditional costing systems, the ratio of costs to charges (RCC) and relative value units (RVUs), usually allocate indirect costs to individual examinations based on a measure of volume. The major management limitation of the traditional cost system is that it is not strategic; that is, it allows cross-subsidies between examinations. Therefore, the changes in the examination costs, shifting from a film-based system to a filmless system, are unclear. In addition, Japanese medical personnel generally have a poor awareness of costs, one reason why costs cannot be precisely estimated.

One particular cost accounting methodology is activity-based costing (ABC). The ABC method measures the cost and performance of activities, resources, and cost

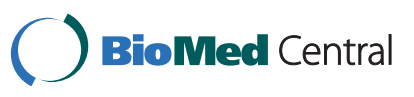


objects $[1,2]$. Works are classified into activities, then resources are assigned to activities, and the latter are assigned to cost objects based on their use. The ABC method recognizes the causal relationships between cost drivers and activities. The advantages of $A B C$ versus RCC and RVUs are as follows: (1) resources consumed at treatment level are more precisely defined and reflected; and (2) resources consumed by a particular cost object are directly tracked and identified to a greater degree [1]. The disadvantages are as follows: (1) $\mathrm{ABC}$ is the newest of the three methods, and therefore not as well known; and (2) the calculation method is complicated because of many allocation bases. ABC has been applied to health care organizations [3-6], and several researchers have applied $A B C$ to radiographic examinations [7-9].

To our knowledge, no study has specifically addressed the changing costs structures of radiographic examinations, resulting the shift from a film-based system to a filmless system. To provide an efficient examination as part of a medical service, it is necessary for the radiologic technologist to understand the actual costs and to apply cost management processes in a filmless system. ABC can accurately calculate to a greater degree the cost of changing resources or procedures by focusing on each activity.

The primary purpose of this study is to identify the cost structure of a radiographic examination, comparing a filmless system with that of a film-based system using the ABC method. To clarify these changing costs and cost structures within the medical service, we simulated radiographic examinations in a health clinic to simplify the flow of duties.

\section{Methods}

\section{Setting and subject}

Two radiologic technologists were interviewed regarding the resources and flows (radiology procedures or activities) of radiographic examinations. An orthopedic health clinic was simulated for a film-based system and a filmless system. The cost objects of the radiographic examinations were lumbar (six views), knee (three views), wrist (two views), and other. The setting was such that radiographic examinations were conducted by a radiologic technologist. The ratio of new patients to re-examined patients in the out-patients department was $6: 1$. The number of radiographic examinations is given in Table 1.

\section{Costs of radiographic examinations}

We calculated the costs of a radiographic examination in a filmless and a film-based system, and assessed the costs or cost components. The direct costs (film cost,
Table 1 Annual number of radiographic examinations

\begin{tabular}{ccc}
\hline Cost objects & New patients & Re-examined patients \\
\hline Lumbar (six views) & 900 & 600 \\
Knee (three views) & 600 & 400 \\
Wrist (two views) & 600 & 400 \\
Other & 900 & 600 \\
Total & 3,000 & 2,000 \\
\hline
\end{tabular}

film-envelope cost, and film-disposal cost) were traced to each examination.

The indirect cost were allocated to cost objects based on the ABC method. First, we extracted the resources consumed by radiographic examinations. The resources assumed the following costs depreciation costs of the equipment/system (CR system, X-ray equipment, dry film imager, viewbox (Schaukasten), information system (PACS, etc)); maintenance costs of the equipment/system (CR system, X-ray equipment, dry film imager, information system (PACS, etc)); labor costs (radiologic technologist, medical office personnel); and other administrative expenses (hospital administration and equipment, expenses for lighting and fuel). Labor costs were calculated by multiplying the time spent doing examination activity with the hourly rate taken from the annual salary (radiologic technologist: 6,000,000 yen; medical office personnel: 2,000,000 yen (1,000 yen/h)).

Second, we defined and classified the activities carried out during radiographic examinations. These activities were recognized as a measurable minimum unit of the consumption of resources. We then classified the activities as main (directly associated with an examination) or support activities (one that supported the examination). In addition, we classified main activities as either primary or secondary activities. Primary activities included face-to-face contact with the patient, and secondary activities supported primary activities [1]. Cost pools, where the costs were grouped together, represented a single activity-similar activities were bound together into a cost pool.

Finally, we set the resource and activity drivers, which were the allocation base. These drivers are the cause of the activity and reveal the effect of the driver. The resource drivers assigned the cost of resources to activities (cost pools) and activity drivers assigned the cost of activities to cost objects.

We also set the time spent on the activity and the machine for the $\mathrm{CR}$ system, $\mathrm{X}$-ray equipment, dry film imager, and viewbox as the allocation base.

\section{Sensitivity analysis}

We performed sensitivity analyses to evaluate the factors that influence the cost price. Examination costs were 
calculated by changing each factor ("the number of examinations," "labor costs," "depreciation costs of the equipment/system," "maintenance costs of the equipment/system," "time (increasing and decreasing by the skill of the personnel or by the disease severity in the patients)," and "other administrative expenses") by $80 \%$ or $120 \%$.

\section{Results}

\section{Examination workflow and length of time}

We simplified the radiographic examination workflow as follows: (1) checking previous patient's images; (2) preparing room and equipment/system; (3) patient's positioning; (4) irradiation; (5) reading images; and (6) aftercare. For each examination, we estimated the time of radiographic examination (Tables 2 and 3 ).

\section{Resources and resource drivers}

The resources used in the radiographic examinations and the resource drivers are given in Tables 4 and 5.

In the filmless system, the direct cost was 0 yen and the indirect cost was $8,354,000$ yen per annum. In the

Table 2 Estimation of length of examination in minutes

\begin{tabular}{|c|c|c|c|c|}
\hline & $\begin{array}{c}\text { Lumbar } \\
(6 \\
\text { views) }\end{array}$ & $\begin{array}{c}\text { Knee } \\
(3 \\
\text { views) }\end{array}$ & $\begin{array}{c}\text { Wrist } \\
(2 \\
\text { views })\end{array}$ & Other \\
\hline \multicolumn{5}{|l|}{ Typically } \\
\hline $\begin{array}{l}\text { Transportation of film/order } \\
\text { slip }\end{array}$ & 0.50 & 0.50 & 0.50 & 0.50 \\
\hline $\begin{array}{l}\text { Registration of patient } \\
\text { information }\end{array}$ & 0.50 & 0.50 & 0.50 & 0.50 \\
\hline Preparing room & 0.25 & 0.25 & 0.25 & 0.25 \\
\hline Calling patient & 0.50 & 0.50 & 0.50 & 0.50 \\
\hline Explanation of scan & 0.50 & 0.50 & 0.50 & 0.50 \\
\hline Changing clothes & 2.00 & 2.00 & 0.00 & 1.33 \\
\hline Positioning & 4.50 & 3.00 & 1.50 & 3.00 \\
\hline Irradiation & 1.50 & 0.75 & 0.50 & 0.92 \\
\hline Reading image & 6.00 & 3.00 & 2.00 & 3.67 \\
\hline Aftercare & 0.50 & 0.50 & 0.50 & 0.50 \\
\hline Changing clothes & 2.00 & 2.00 & 0.00 & 1.33 \\
\hline Opinion/transmission & 1.50 & 0.75 & 0.50 & 0.92 \\
\hline $\begin{array}{l}\text { Transportation of film/order } \\
\text { slip }\end{array}$ & 0.50 & 0.50 & 0.50 & 0.50 \\
\hline \multicolumn{5}{|l|}{ Filmless system only } \\
\hline $\begin{array}{l}\text { Searching/checking previous } \\
\text { image }\end{array}$ & 1.00 & 1.00 & 1.00 & 1.00 \\
\hline \multicolumn{5}{|l|}{ Film-based system only } \\
\hline $\begin{array}{l}\text { Preparation of previous film } \\
\text { image }\end{array}$ & 2.00 & 2.00 & 2.00 & 2.00 \\
\hline $\begin{array}{l}\text { Checking previous film } \\
\text { image }\end{array}$ & 1.00 & 1.00 & 1.00 & 1.00 \\
\hline Printing film & 6.00 & 3.00 & 2.00 & 3.67 \\
\hline Preparation of film envelope & 0.50 & 0.50 & 0.50 & 0.50 \\
\hline Checking film image & 1.50 & 0.75 & 0.50 & 0.92 \\
\hline
\end{tabular}

Table 3 Estimation of length of activity and machine per annum in minutes

\begin{tabular}{lcc}
\hline & Filmless system & Film-based system \\
\hline CR system & 30,500 & 30,500 \\
X-ray equipment & 43,375 & 43,375 \\
Viewbox & & 6,875 \\
Radiologic technologist & 48,250 & 72,625 \\
Medical office personnel & 2,500 & 6,500 \\
\hline
\end{tabular}

film-based system, the direct cost was 3,880,000 yen and the indirect cost was $8,870,000$ yen per annum. It was shown that the cost of a radiographic examination was reduced by $34.5 \%$ using a filmless system. Resource drivers were identified as "number of films (irradiation)," "number of examinations," and "activity or machine time" for each resource.

\section{Cost of radiographic examination and cost structure}

Activity costs and examination costs are given in Tables 6 and 7. During a radiographic examination in a filmless system there are 13 main activities, 3 support activities, and 12 cost pools. In a film-based system, there are 18 main activities 2 support activities, and 17 cost pools.

The cost of various radiographic examinations using a filmless system are as follows: lumbar (6 views) 2,085 yen; knee ( 3 views) 1,599 yen; wrist (2 views) 1,165 yen, and other 1,641 yen. With regard to the cost structure of radiographic examinations using a filmless system, "maintenance of the equipment/system" represented $29.9 \%$ of the total cost, "take photographs (reading image)" 28.7\%, and "imaging administration by PACS" $12.0 \%$.

Table 4 Resources per annum and resource drivers for a filmless system

\begin{tabular}{lccl}
\hline & $\begin{array}{c}\text { Cost } \\
\text { (yen) }\end{array}$ & $\begin{array}{c}\text { Resource driver } \\
\text { (yen) }\end{array}$ \\
\hline Direct costs & & & \\
\hline Total & 0 & & \\
\hline Indirect costs & & & \\
CR system & $1,600,000$ & 52.5 & /minute \\
Depreciation of CR system & $1,000,000$ & 2000 /examination \\
X-ray equipment & 600,000 & 13.8 /minute \\
Depreciation of X-ray equipment & $1,000,000$ & 200.0 /examination \\
Information system & $1,000,000$ & 50.0 /view \\
Depreciation of information & 500,000 & 100.0 /examination \\
system & & & \\
Radiologic technologist & $2,412,500$ & 50.0 & /minute \\
Medical office personnel & 41,667 & 16.7 & /minute \\
Administration & 200,000 & 40.0 & /examination \\
\hline Total & $8,354,167$ & & \\
\hline Total cost & $8,354,167$ & & \\
\hline
\end{tabular}


Table 5 Resources per annum and resource drivers for a film-based system

\begin{tabular}{lccl}
\hline & Cost (yen) & $\begin{array}{c}\text { Resource driver } \\
\text { (yen) }\end{array}$ \\
\hline Direct costs & $3,180,000$ & 159.0 /film \\
Film (B5) & 100,000 & 20.0 /examination \\
Film envelope & 600,000 & 30.0 /film \\
Film disposal & $3,880,000$ & & \\
\hline Total & & & \\
\hline Indirect costs & $1,600,000$ & 52.5 & /minute \\
CR system & $1,000,000$ & 2000 /examination \\
Depreciation of CR system & 600,000 & 13.8 /minute \\
X-ray equipment & $1,000,000$ & 200.0 /examination \\
Depreciation of X-ray equipment & 400,000 & 20.0 /film \\
Dry film imager & 300,000 & 60.0 /examination \\
Depreciation of dry film imager & 30,000 & 4.4 /minute \\
Viewbox & $3,631,250$ & 50.0 /minute \\
Radiologic technologist & 108,333 & 16.7 /minute \\
Medical office personnel & 200,000 & 40.0 /examination \\
Administration & $8,869,583$ & \\
\hline Total & $12,749,583$ & \\
\hline Total cost & &
\end{tabular}

The examination costs for a film-based system are as follows lumbar (6 views) 3,407 yen; knee (3 views) 2,257 yen; wrist (2 views) 1,602 yen, and other 2,521 yen. The greatest cost in the cost structure was that of film costs (24.9\% of the total cost), then "take photographs (reading image)" at $18.8 \%$, "maintenance of the equipment/ system" was $18.0 \%$, and "printing film (preparation of film envelope)" was $10.8 \%$.

The primary activities were "calling patient," "explanation of scan," "take photographs," and "aftercare" for both filmless and film-based systems. These activities cost $36.0 \%$ of the total cost for a filmless system and $23.6 \%$ for a film-based system.

\section{Sensitivity analysis}

The result of the sensitivity analyses are given in Tables 8 and 9. "The number of examinations" was the parameter that most influenced the examination costs for both systems; however, it had a greater influence on examination costs under a filmless system than that of a film-based system. For example, lumbar examinations in a filmless system ranged from 1,844 yen $(88.4 \%)$ to 2,447 yen (117.3\%), whereas the costs ranged from 3,201

Table 6 Cost of radiographic examination for a filmless system

\begin{tabular}{|c|c|c|c|c|c|c|c|}
\hline \multicolumn{2}{|l|}{ Cost objects } & \multirow{3}{*}{$\begin{array}{c}\begin{array}{c}\text { Lumbar (6 } \\
\text { views) }\end{array} \\
\text { Cost (yen) }\end{array}$} & \multirow{3}{*}{$\begin{array}{c}\begin{array}{c}\text { Knee (3 } \\
\text { views) }\end{array} \\
\text { Cost (yen) }\end{array}$} & \multirow{3}{*}{$\begin{array}{c}\begin{array}{c}\text { Wrist (2 } \\
\text { views) }\end{array} \\
\text { Cost (yen) }\end{array}$} & \multirow{3}{*}{$\begin{array}{c}\text { Other } \\
\\
\text { Cost } \\
\text { (yen) }\end{array}$} & \multicolumn{2}{|c|}{ Total } \\
\hline \multicolumn{4}{|l|}{ Indirect costs } & & & & \\
\hline Activity (Cost pool) & Activity driver & & & & & $\begin{array}{l}\text { Cost } \\
\text { (yen) }\end{array}$ & Rate \\
\hline \multicolumn{8}{|l|}{ Main activity } \\
\hline Transportation of order slip & 8.33 /examination & 12,500 & 8,333 & 8,333 & 12,500 & 41,667 & $0.5 \%$ \\
\hline Registration of patient information & 51.23 /examination & 76,844 & 51,230 & 51,230 & 76,844 & 256,148 & $3.1 \%$ \\
\hline Searching/checking previous image & 50.00 /examination & 30,000 & 20,000 & 20,000 & 30,000 & 100,000 & $1.2 \%$ \\
\hline Preparating room & 63.83 /minute & 23,937 & 15,958 & 15,958 & 23,937 & 79,791 & $1.0 \%$ \\
\hline Calling patient & 63.83 /minute & 47,875 & 31,916 & 31,916 & 47,875 & 159,582 & $1.9 \%$ \\
\hline Explanation of scan & 63.83 /minute & 47,875 & 31,916 & 31,916 & 47,875 & 159,582 & $1.9 \%$ \\
\hline Changing clothes & 63.83 /minute & 191,499 & 127,666 & 0 & 127,666 & 446,830 & $5.3 \%$ \\
\hline Take photographs (reading image) & 116.29 /minute & $1,046,627$ & 436,095 & 232,584 & 683,215 & $2,398,520$ & $28.7 \%$ \\
\hline Aftercare & 116.29 /minute & 87,219 & 58,146 & 58,146 & 87,219 & 290,730 & $3.5 \%$ \\
\hline Changing clothes & 13.83 /minute & 41,499 & 27,666 & 0 & 27,666 & 96,830 & $1.2 \%$ \\
\hline Opinion/Transmission & 24.97 /view & 224,769 & 74,923 & 49,949 & 149,846 & 499,488 & $6.0 \%$ \\
\hline Transportation of order slip & 25.00 /examination & 37,500 & 25,000 & 25,000 & 37,500 & 125,000 & $1.5 \%$ \\
\hline \multicolumn{8}{|l|}{ Support activity } \\
\hline Imaging administration by PACS & 50.00 /view & 450,000 & 150,000 & 100,000 & 300,000 & $1,000,000$ & $12.0 \%$ \\
\hline $\begin{array}{c}\text { Maintenance of the equipment/ } \\
\text { system }\end{array}$ & 500.00 /examination & 750,000 & 500,000 & 500,000 & 750,000 & $2,500,000$ & $29.9 \%$ \\
\hline Other administration & 40.00 /examination & 60,000 & 40,000 & 40,000 & 60,000 & 200,000 & $2.4 \%$ \\
\hline Indirect costs total & & $3,128,143$ & $1,598,849$ & $1,165,032$ & $2,462,142$ & $8,354,167$ & $100.0 \%$ \\
\hline \multicolumn{8}{|l|}{ Direct cost } \\
\hline Direct costs total & & 0 & 0 & 0 & 0 & 0 & $0.0 \%$ \\
\hline Total cost & & $3,128,143$ & $1,598,849$ & $1,165,032$ & $2,462,142$ & $8,354,167$ & $100.0 \%$ \\
\hline Cost of radiographic examination & & 2,085 & 1,599 & 1,165 & 1,641 & & \\
\hline
\end{tabular}


Table 7 Cost of radiographic examination for a film-based system

\begin{tabular}{|c|c|c|c|c|c|c|c|}
\hline \multicolumn{2}{|l|}{ Cost objects } & \multirow{2}{*}{$\begin{array}{c}\text { Lumbar (6 } \\
\text { views) }\end{array}$} & \multirow{2}{*}{$\begin{array}{c}\text { Knee (3 } \\
\text { views) }\end{array}$} & \multirow{2}{*}{$\begin{array}{l}\text { Wrist (2 } \\
\text { views) }\end{array}$} & \multirow[t]{2}{*}{ Other } & \multicolumn{2}{|c|}{ Total } \\
\hline \multicolumn{4}{|l|}{ Indirect costs } & & & & \\
\hline Activity (Cost pool) & Activity driver & Cost (yen) & Cost (yen) & Cost (yen) & $\begin{array}{l}\text { Cost } \\
\text { (yen) }\end{array}$ & Cost (yen) & Rate \\
\hline \multicolumn{8}{|l|}{ Main activity } \\
\hline Prepare previous film image & 33.33 /examination & 20,000 & 13,333 & 13,333 & 20,000 & 66,667 & $0.5 \%$ \\
\hline Transportation of film/order slip & 8.33 /examination & 12,500 & 8,333 & 8,333 & 12,500 & 41,667 & $0.3 \%$ \\
\hline Registration of patient information & 51.23 /examination & 76,844 & 51,230 & 51,230 & 76,844 & 256,148 & $2.0 \%$ \\
\hline Checking previous film image & 54.36 /examination & 32,618 & 21,745 & 21,745 & 32,618 & 108,727 & $0.9 \%$ \\
\hline Preparing room & 63.83 /minute & 23,937 & 15,958 & 15,958 & 23,937 & 79,791 & $0.6 \%$ \\
\hline Calling patient & 63.83 /minute & 47,875 & 31,916 & 31,916 & 47,875 & 159,582 & $1.3 \%$ \\
\hline Explanation of scan & 63.83 /minute & 47,875 & 31,916 & 31,916 & 47,875 & 159,582 & $1.3 \%$ \\
\hline Changing clothes & 63.83 /minute & 191,499 & 127,666 & 0 & 127,666 & 446,830 & $3.5 \%$ \\
\hline Take photographs (reading image) & 116.29 /minute & $1,046,627$ & 436,095 & 232,584 & 683,215 & $2,398,520$ & $18.8 \%$ \\
\hline Aftercare & 116.29 /minute & 87,219 & 58,146 & 58,146 & 87,219 & 290,730 & $2.3 \%$ \\
\hline Changing clothes & 13.83 /minute & 41,499 & 27,666 & 0 & 27,666 & 96,830 & $0.8 \%$ \\
\hline Opinion/Transmission & 24.97 /view & 224,769 & 74,923 & 49,949 & 149,846 & 499,488 & $3.9 \%$ \\
\hline $\begin{array}{c}\text { Printing film (preparation of film } \\
\text { envelope) }\end{array}$ & 68.75 /view & 618,750 & 206,250 & 137,500 & 412,500 & $1,375,000$ & $10.8 \%$ \\
\hline Checking film image & 13.25 /view & 119,260 & 39,753 & 26,502 & 79,507 & 265,023 & $2.1 \%$ \\
\hline Transportation of film/order slip & 25.00 /examination & 37,500 & 25,000 & 25,000 & 37,500 & 125,000 & $1.0 \%$ \\
\hline \multicolumn{8}{|l|}{ Support activity } \\
\hline Maintenance of the equipment/system & 460.00 /examination & 690,000 & 460,000 & 460,000 & 690,000 & $2,300,000$ & $18.0 \%$ \\
\hline Other administration & 40.00 /examination & 60,000 & 40,000 & 40,000 & 60,000 & 200,000 & $1.6 \%$ \\
\hline Indirect costs total & & $3,378,772$ & $1,669,931$ & $1,204,113$ & $2,616,767$ & $8,869,583$ & $69.6 \%$ \\
\hline \multicolumn{8}{|l|}{ Direct costs } \\
\hline Film (B5) & 159.0 /film & $1,431,000$ & 477,000 & 318,000 & 954,000 & $3,180,000$ & $24.9 \%$ \\
\hline Film envelope & 20.0 & 30,000 & 20,000 & 20,000 & 30,000 & 100,000 & $0.8 \%$ \\
\hline Film disposal & 30.0 /film & 270,000 & 90,000 & 60,000 & 180,000 & 600,000 & $4.7 \%$ \\
\hline Direct costs total & & $1,731,000$ & 587,000 & 398,000 & $1,164,000$ & $3,880,000$ & $30.4 \%$ \\
\hline Total cost & & $5,109,772$ & $2,256,931$ & $1,602,113$ & $3,780,767$ & $12,749,583$ & $100.0 \%$ \\
\hline Cost of radiographic examination & & 3,407 & 2,257 & 1,602 & 2,521 & & \\
\hline
\end{tabular}

yen $(94.0 \%)$ to 3,715 yen $(109.1 \%)$ for a film-based system.

\section{Discussion}

In this study, we calculated the costs of radiographic examinations in both a filmless system and a film-based system using the $\mathrm{ABC}$ method. Our results indicate that examination costs and cost structures can be expressed by identifying activity costs.

In recent times, hospital management has both emphasized and relied on knowledge regarding the cost of clinical examinations. However, estimating actual examination costs using traditional costing methods is difficult because radiographic examinations include many indirect costs, and the implementation of filmless systems has increased this trend. The ABC method can visualize the operation from a cost standpoint using costing based on relevant activities. Therefore when an operation is improved or evaluated and an equipment/ system is introduced or updated, the ABC method can manage the cost of the procedure or support decisionmaking by clarifying the issue or estimating the improvement effect. Additionally, $\mathrm{ABC}$ may be able to heighten the awareness of medical personnel regarding costs by calculating accessible activity costs.

The introduction of filmless systems has resulted in various cost reductions in the use of different types of photography: the higher the number of images, the greater the reduction in costs. The rate of reduction in costs was higher for lumbar examinations (6 views) $(38.78 \%)$. This result demonstrates that the reduction in film cost had the greatest impact on total cost: film cost was $24.9 \%$ of the total cost.

The rate of primary activity increased by $23.6-36.0 \%$ because of the implementation of the filmless system. In particular, the activity rate of "take photographs" 
Table 8 Sensitivity analyses of examination costs for a filmless system

\begin{tabular}{|c|c|c|c|c|c|c|c|c|c|}
\hline & & Lumbar(yen) & & Knee(yen) & & t(yen) & & Other(yen) & \\
\hline \multirow[t]{2}{*}{ Number of examinations } & $80 \%$ & 2,447 & $117.3 \%$ & 1,876 & $117.3 \%$ & 1,384 & $118.8 \%$ & 1,933 & $117.7 \%$ \\
\hline & $120 \%$ & 1,844 & $88.4 \%$ & 1,414 & $88.4 \%$ & 1,019 & $87.5 \%$ & 1,447 & $88.2 \%$ \\
\hline \multirow[t]{2}{*}{ Labor costs } & $80 \%$ & 1,958 & $93.9 \%$ & 1,501 & $93.9 \%$ & 1,107 & $95.0 \%$ & 1,546 & $94.2 \%$ \\
\hline & $120 \%$ & 2,213 & $106.1 \%$ & 1,697 & $106.1 \%$ & 1,223 & $105.0 \%$ & 1,737 & $105.8 \%$ \\
\hline \multirow[t]{2}{*}{ Depreciation costs of equipment } & $80 \%$ & 1,964 & $94.2 \%$ & 1,515 & $94.8 \%$ & 1,118 & $96.0 \%$ & 1,557 & $94.8 \%$ \\
\hline & $120 \%$ & 2,207 & $105.8 \%$ & 1,683 & $105.2 \%$ & 1,212 & $104.0 \%$ & 1,726 & $105.2 \%$ \\
\hline \multirow[t]{2}{*}{ Depreciation costs of system } & $80 \%$ & 2,025 & $97.1 \%$ & 1,569 & $98.1 \%$ & 1,145 & $98.3 \%$ & 1,601 & $97.6 \%$ \\
\hline & $120 \%$ & 2,145 & $102.9 \%$ & 1,629 & $101.9 \%$ & 1,185 & $101.7 \%$ & 1,681 & $102.4 \%$ \\
\hline \multirow[t]{2}{*}{ Maintenance costs of equipment } & $80 \%$ & 1,985 & $95.2 \%$ & 1,499 & $93.7 \%$ & 1,065 & $91.4 \%$ & 1,541 & $93.9 \%$ \\
\hline & $120 \%$ & 2,185 & $104.8 \%$ & 1,699 & $106.3 \%$ & 1,265 & $108.6 \%$ & 1,741 & $106.1 \%$ \\
\hline \multirow[t]{2}{*}{ Maintenance costs of system } & $80 \%$ & 2,065 & $99.0 \%$ & 1,579 & $98.7 \%$ & 1,145 & $98.3 \%$ & 1,621 & $98.8 \%$ \\
\hline & $120 \%$ & 2,105 & $101.0 \%$ & 1,619 & $101.3 \%$ & 1,185 & $101.7 \%$ & 1,661 & $101.2 \%$ \\
\hline \multirow[t]{2}{*}{ Time (skill of personnel) } & $80 \%$ & 1,978 & $94.9 \%$ & 1,524 & $95.3 \%$ & 1,103 & $94.7 \%$ & 1,559 & $95.0 \%$ \\
\hline & $120 \%$ & 2,193 & $105.1 \%$ & 1,675 & $104.7 \%$ & 1,226 & $105.2 \%$ & 1,724 & $105.0 \%$ \\
\hline \multirow[t]{2}{*}{ Time (disease severity of patients) } & $80 \%$ & 2,006 & $96.2 \%$ & 1,530 & $95.7 \%$ & 1,137 & $97.6 \%$ & 1,583 & $96.5 \%$ \\
\hline & $120 \%$ & 2,165 & $103.8 \%$ & 1,667 & $104.2 \%$ & 1,194 & $102.5 \%$ & 1,700 & $103.5 \%$ \\
\hline \multirow[t]{2}{*}{ Other administrative expenses } & $80 \%$ & 2,077 & $99.6 \%$ & 1,591 & $99.5 \%$ & 1,157 & $99.3 \%$ & 1,633 & $99.5 \%$ \\
\hline & $120 \%$ & 2,093 & $100.4 \%$ & 1,607 & $100.5 \%$ & 1,173 & $100.7 \%$ & 1,649 & $100.5 \%$ \\
\hline
\end{tabular}

increased by $18.8-27.8 \%$. This increase in the primary activity rate indicates that the system is cost-effective; therefore such primary activities can provide greater value directly to patients.

Furthermore, the present study confirms that the number of examinations had the greatest influence on examination costs using a filmless system compared with a film-based system. If the number of examinations increased or decreased using a film-based system, the effect on the examination cost was slight because the direct cost rate (e.g., film or film envelope) is higher. Conversely, for a filmless system, the number of examinations had a much greater impact on examination cost; hence a plan to increase the number of examinations is necessary.

The present study does have its limitations. First, clinic costs need to be allocated to each department to accurately calculate examination costs. However, we were interested in the change in costs or cost structures with the introduction of the new system. Therefore, in this study, a clinic's general expenses were not considered. Second, the cost objects only included the main examinations, and operations only included examination flow. Ideally every examination should be included, and re-imaging or the time required for administrative work should also be considered. In addition, the accurate

Table 9 Sensitivity analyses of examination costs for a film-based system

\begin{tabular}{|c|c|c|c|c|c|c|c|c|c|}
\hline & & Lumbar(yen) & & Knee(yen) & & List(yen) & & Other(yen) & \\
\hline \multirow[t]{2}{*}{ Number of examinations } & $80 \%$ & 3,715 & $109.1 \%$ & 2,503 & $110.9 \%$ & 1,797 & $112.2 \%$ & 2,773 & $110.0 \%$ \\
\hline & $120 \%$ & 3,201 & $94.0 \%$ & 2,093 & $92.7 \%$ & 1,472 & $91.9 \%$ & 2,352 & $93.3 \%$ \\
\hline \multirow[t]{2}{*}{ Labor costs } & $80 \%$ & 3,203 & $94.0 \%$ & 2,120 & $93.9 \%$ & 1,517 & $94.7 \%$ & 2,374 & $94.2 \%$ \\
\hline & $120 \%$ & 3,610 & $106.0 \%$ & 2,394 & $106.1 \%$ & 1,687 & $105.3 \%$ & 2,667 & $105.8 \%$ \\
\hline \multirow[t]{2}{*}{ Depreciation costs of equipment } & $80 \%$ & 3,260 & $95.7 \%$ & 2,160 & $95.7 \%$ & 1,546 & $96.5 \%$ & 2,418 & $96.0 \%$ \\
\hline & $120 \%$ & 3,553 & $104.3 \%$ & 2,354 & $104.3 \%$ & 1,658 & $103.5 \%$ & 2,623 & $104.0 \%$ \\
\hline \multirow[t]{2}{*}{ Maintenance costs of equipment } & $80 \%$ & 3,315 & $97.3 \%$ & 2,165 & $95.9 \%$ & 1,510 & $94.3 \%$ & 2,429 & $96.3 \%$ \\
\hline & $120 \%$ & 3,499 & $102.7 \%$ & 2,349 & $104.1 \%$ & 1,694 & $105.7 \%$ & 2,613 & $103.7 \%$ \\
\hline \multirow[t]{2}{*}{ Time (skill of personnel) } & $80 \%$ & 3,320 & $97.5 \%$ & 2,196 & $97.3 \%$ & 1,542 & $96.3 \%$ & 2,449 & $97.2 \%$ \\
\hline & $120 \%$ & 3,531 & $103.7 \%$ & 2,343 & $103.8 \%$ & 1,671 & $104.3 \%$ & 2,615 & $103.8 \%$ \\
\hline \multirow[t]{2}{*}{ Time (disease severity of patients) } & $80 \%$ & 3,328 & $97.7 \%$ & 2,188 & $97.0 \%$ & 1,574 & $98.2 \%$ & 2,462 & $97.7 \%$ \\
\hline & $120 \%$ & 3,486 & $102.3 \%$ & 2,325 & $103.0 \%$ & 1,631 & $101.8 \%$ & 2,579 & $102.3 \%$ \\
\hline \multirow[t]{2}{*}{ Other administrative expenses } & $80 \%$ & 3,399 & $99.8 \%$ & 2,249 & $99.6 \%$ & 1,594 & $99.5 \%$ & 2,513 & $99.7 \%$ \\
\hline & $120 \%$ & 3,415 & $100.2 \%$ & 2,265 & $100.4 \%$ & 1,610 & $100.5 \%$ & 2,529 & $100.3 \%$ \\
\hline
\end{tabular}


measurement of time is indispensable to determine the actual cost of examinations.

\section{Conclusions}

The costs and cost structures of radiographic examinations using a filmless system and a film-based system were calculated using the $\mathrm{ABC}$ method. The cost objects were lumbar (6 views), knee (3 views), wrist (2 views), and other, with costs of 2,085, 1,599, 1,165, and 1,641 yen, respectively for a filmless system.3,407, 2,257, 1,602, and 2,521 yen, respectively, for a film-based system. Our results provide clear evidence that the filmless system is more effective than the film-based system in providing services of greater value directly to patients.

\section{Author details}

'Graduate School of Health Sciences, Hokkaido University, N12W5, Kita-ku, Sapporo, 060-0812, Japan. ²Department of Radiology, Itoh Orthopaedic Hospital, 5, S2W10, Chuou-ku, Sapporo, 060-0062, Japan. ${ }^{3}$ Faculty of Management, Dohto University, 149, Nakanosawa, Kitahiroshima, 061-1196, Japan.

\section{Authors' contributions}

HM performed the investigation. HM analyzed the data. HM wrote the manuscript. HM, YT, SS, YY, TA, YS and KO interpreted the data and contributed substantially to its revision. $\mathrm{KO}$ conceived the study, and participated in its design and coordination and helped to draft the manuscript. All the authors read and approved the final manuscript.

\section{Competing interests}

The authors declare that they have no competing interests.

Received: 24 September 2010 Accepted: 30 September 2011 Published: 30 September 2011

\section{References}

1. Baker JJudith: Activity-based costing and activity-based management for health care. Aspen Publishers, Gaithersburg, Maryland 1998.

2. Kaplan RS, Anderson SR: Time-driven activity-based costing. Harv Bus Rev 2004, 82(11):131-138.

3. Laurila J, Suramo I, Brommels M, Tolppanen EM, Koivukangas $P$, Standertskjold-Nordenstam G: Activity-based costing in radiology. Application in a pediatric radiological unit. Acta Radiol 2000, 41(2):189-195.

4. Storfjell JL, Omoike $\mathrm{O}$, Ohlson S: The balancing act: patient care time versus cost. J Nurs Adm 2008, 38(5):244-249.

5. Demeere N, Stouthuysen K, Roodhooft F: Time-driven activity-based costing in an outpatient clinic environment: development, relevance and managerial impact. Health Policy 2009, 92(2-3):296-304.

6. Cao P, Toyabe S, Kurashima S, Okada M, Akazawa K: A modified method of activity-based costing for objectively reducing cost drivers in hospitals. Methods Inf Med 2006, 45(4):462-469.

7. Krug B, Van Zanten A, Pirson AS, Crott R, Borght TV: Activity-based costing evaluation of a [(18)F]-fludeoxyglucose positron emission tomography study. Health Policy 2009, 92(2-3):234-43.

8. Suthummanon S, Omachonu VK, Akcin M: Applying activity-based costing to the nuclear medicine unit. Health Serv Manage Res 2005, 18(3):141-50.

9. Nisenbaum HL, Birnbaum BA, Myers MM, Grossman Rl, Gefter WB, Langlotz CP: The costs of $C T$ procedures in an academic radiology department determined by an activity-based costing (ABC) method. J Comput Assist Tomogr 2000, 24(5):813-23.

Pre-publication history

The pre-publication history for this paper can be accessed here: http://www.biomedcentral.com/1472-6963/11/246/prepub doi:10.1186/1472-6963-11-246

Cite this article as: Muto et al:: Filmless versus film-based systems in radiographic examination costs: an activity-based costing method. BMC Health Services Research 2011 11:246.

\section{Submit your next manuscript to BioMed Central and take full advantage of:}

- Convenient online submission

- Thorough peer review

- No space constraints or color figure charges

- Immediate publication on acceptance

- Inclusion in PubMed, CAS, Scopus and Google Scholar

- Research which is freely available for redistribution 